\title{
Green Economy as a Direction of Sustainable Development of Coastal Areas*
}

\author{
Evgeniya Arumova \\ Department of Public and Municipal Administration \\ Kuban State University \\ Krasnodar, Russia \\ E-mail: arumova.kubsu@ mail.ru
}

\author{
Maria Bitarova \\ Science and Technology Park \\ Technopark University \\ Kuban State University \\ Krasnodar, Russia \\ E-mail: bitarova@mail.ru
}

\author{
Elena Belyaeva \\ Department of Public and Municipal Administration \\ Kuban State University \\ Krasnodar, Russia \\ E-mail: helenla@mail.ru \\ Veronika Panaseykina \\ Department of Public and Municipal Administration \\ Kuban State University \\ Krasnodar, Russia \\ E-mail: vspjuly@mail.ru
}

\begin{abstract}
The article is devoted to the mainstream trends of green market development as a direction of sustainable development of coastal areas. The goals and principles of the policy of green economy in coastal territories are defined. The key tools for the transition of coastal areas to a green economy are described. The main innovative mechanisms of sustainable development of coastal territories are considered.
\end{abstract}

Keywords - coastal area; coastal territories; green economy; integrated coastal area management (ICAM); sustainable development

\section{INTRODUCTION}

Some issues of transition to a green economy were raised at one of the major UN conferences in Rio de Janeiro in 2012, dedicated to the 20th anniversary of the 1992 United Nations Conference on Environment and Development (UNCED) (Rio+20). Such terms as "green industry", "green markets", "green employment" and other combinations with "green" are becoming widely used in international instruments.

International experts consider green growth and an updated option of sustainable development as a new engine of the economy enable to cope with certain challenges of modern social and economic development [1].

Summarizing the authors' opinions in various reports and practical works on the green economy, it can be noted that for scientists and researchers the green economy means an "action-oriented approach to achieve sustainable development". That is, the green economy is frequently

*Fund: The article has been prepared for publication under the sponsorship of the Russian Foundation for Basic Research, project No. 19010-00194 A; The article has been prepared for publication under the sponsorship of the President of the Russian Federation for state support of young Russian scientists - doctors of sciences MD-402.2019.6 interpreted as a set of tools allowing for a shift towards more sustainable and environmentally responsible production and consumption.

Green economy assumes a reasonable balance between social and economic development of coastal territories and natural environment preservation, introduction of green standards at the enterprises contributing to a decrease in loading on natural environment and, consequently, a rise in ecological and economic balance of development on such territories. Utilizing green technology in production processes will lead to a higher resource efficiency and nonwastefulness compared to traditional techniques, which, in turn, will create a solid background for environmentally friendly and cost-effective production. For the subsequent market development of environmentally friendly products and technologies, equipment and services, it is necessary to implement a set of organizational, managerial, economic and administrative measures. Thus, promoting environmentally friendly products depends primarily on the presence of an environmental factor in various economic indicators. Hence, compliance with principles for the green economy has a positive impact on the investment attractiveness of coastal areas, including when reducing environmental risk.

\section{OBJECTIVES AND PRINCIPLES OF GREEN ECONOMY IN COASTAL AREAS}

The transition of coastal areas to a green economy is based on a number of principles, including:

- economic upgrade of coastal territories. These transformations provide wide opportunities to apply completely new solutions in the economy, such as new closed-cycle technologies based on production integration or innovative approaches to power generation in coastal areas; 
recreational facilities using green technologies. In this regard, some relevant incentive tools are introducing tax incentives for green projects, implementing state programmes in the field of ecological construction, subsidizing for green projects and developing national standards of ecological construction [3].

Another area to implement sustainable production and consumption models for coastal areas is green shipping.

There is a growing trend towards building environmentally friendly ships, as well as a growing awareness to reduce carbon dioxide emissions from vessels. Ship characteristics such as gas engines, new hull design, more energy efficient materials and "clean (environmentally friendly) engines" are being increasingly demanded with shipowners. Shipyards are also involved by investing in skills, technologies and processes needed to produce such vessels. [4];

- reducing harmful effects on the environment (green technologies and alternative fuels as a means for lowering the anthropogenic impact on land-sea ecosystem);

- social goals, which are creating new green jobs, improvement of habitat and quality of life of the population of coastal territories [2]

A general review of available literature sources on sustainable development allowed identifying mechanisms for achieving goals of coastal areas development based on green economy:

\section{A. Reforming the Budgetary System by Introducing Environmental Taxes}

Eco-taxes are primarily introduced to redistribute the tax burden from socially significant activities (for example, employment) to activities that harm the environment. In addition, the reallocation of budget funds to increase investment of environmentally friendly activities, such as improving transport infrastructure and public transport for reducing air pollution in large cities, is also one of the measures to reform the tax system. The goal is not to increase the tax burden, but to take effective and efficient measures to protect the environment and preserve natural capital for future generations.

\section{B. Introducing Models of Sustainable Production and Consumption}

The models of sustainable consumption and production, which imply achieving greater and better results at the lowest cost, are implemented to design a process, in which economic growth does not depend on the ever-increasing demand for natural resources and on environmental degradation. This can be achieved by reducing the material and energy intensity of current economic activities, as well as by reducing emissions and waste while extracting, producing, consuming and disposing.

In order to ensure sustainable development of coastal areas, it is advisable to encourage the construction of

\section{Developing a Green Business}

Socially responsible green business is focused on utilizing renewable natural resources, producing environmentally friendly products, and applying low-waste and resource-saving technologies. Developing a green business is also promoted by various forms of public-private partnership, including the environmental partnerships, which are currently actively developing and are supported by private and public institutions [5];

\section{Creating a Sustainable Infrastructure}

Particular attention in the transition of coastal areas to a green economy should be paid to creating modern infrastructure, which is key to sustainable development. The infrastructure sectors include water infrastructure (including dams and reservoirs), land management and planning, housing and urban development, coastal flood protection, road transport infrastructure (including ports, bridges, roads), number of others.

\section{GREEN ECONOMY TRANSITION TOOLS FOR COASTAL TERRITORIES}

A wide range of tools are used to transit to a green economy all over the world including:

- a system of environment-oriented public procurement aimed at stimulating the environmentally friendly production and energy-efficient production methods;

- public-private partnership in the area of environment;

- growing public investment in infrastructures, which are prioritized for the green economy development;

- environmental and social business responsibility;

- targeted state support for research and development related to designing energy-efficient and innovative environmental production technologies [6]. power engineering (including nuclear power plants) and a 


\section{A. Measures of State Stimulation of Investing Green Projects Connected with Environmentally Friendly Technologies, in Particular with Alternative Energy Technology}

Such measures can be implemented as a part of a GIS scheme used in the world practice.

The GIS is an innovative financial mechanism based on voluntary commitment to reinvest the incomes from the sale of the surplus of the national quota in projects to improve energy efficiency of production and consumption, and develop renewable energy sources. The GIS mechanism allows a project to have a status of a Kyoto Protocol project, which significantly reduces investment risks and helps to find funding, while the procedures are much freer than in the JI projects. In addition, this scheme allows to direct funds to social and educational goals, health and nature conservation.

Another tool to stimulate investment in green projects is establishing specialized financial and credit institutions, such as the UK Green Investment Bank plc (GIB), which has successfully operated in the UK.

Tax incentives can encourage green economy investment and private fund raising. Such incentives can be targeted at both consumption and production of goods or services.

Tools for implementing these measures can also include incentive programmes and subsidies for investments in clean power generation, concessional lending and taxation of modernization projects, a system of green certification, etc. [7];

\section{B. Measures of State Support for the Development of Green Employment}

A key element of environmentally sustainable economic and social development of coastal areas is considered to be progress towards a green economy that creates green jobs and increases the environmental safety of organizations aimed at greening production processes and workplaces. This involves concerted efforts jointly executed by the government, employers and trade unions to develop and implement environmentally sustainable and coherent policies, as well as effective programmes aimed at creating green jobs.

Measures aimed at creating green jobs will lead to an increase in employment and become self-supporting when tax bases expand and supplementary financing for national welfare system is provided.

The tool to stimulate green jobs is the development of green jobs state programmes, which should be coordinated and combined with programmes of economic diversification and investment in a green economy.

\section{Measures of State Stimulation of Development of Ecological Tourism and Green Innovations in Tourism in Coastal Territories}

Stimulating the development of eco-tourism services in coastal areas is crucial for preserving biodiversity of land-sea ecosystem and contributes to their transition to a green economy [7]. 
According to international studies, universities can play

The development of eco-tourism in coastal areas requires the preparation and implementation of a number of measures, including:

- drafting and improvement of normative legal acts that contribute to the creation of social, environmental, economic and organizational conditions for the development of eco-tourism;

- favorable conditions for investment through the state support and market mechanisms to ensure the development of eco-tourism by financing for sustainable tourism investment projects of all sizes, targeted programmes of tourism development, funds of private investors, bank loans, etc.

- data centers for eco-tourism promotion in the market of tourist services.

The greening of tourism involves green innovations when constructing accommodation facilities, environmentally friendly transport, as well as household waste sorting and recycling, etc.

Green innovations in coastal tourism can lead to improvement of existing business models, thus benefiting companies, customers, public authorities and local communities through creating new job and improving living conditions

\section{Measures to Create Green Tourist Clusters in Coastal Areas}

These clusters created by governments, regional and local authorities are designed to unite the efforts of the state and business aimed at the development of eco-tourism and green innovation as well as to ensure interacting cluster residents and expanding their competitive advantages.

In order to establish green tourism clusters in the coastal areas, it is necessary to have a number of prerequisites, in particular:

- strategic documents on sustainable development and greening of the regional economy. Given a close connection of coastal areas as tourist destinations with regional development, it is very important to take into account the criterion associated with sustainable territorial development when evaluating the potential of clustering. One of the requirements is effective policy documents (sustainable development concepts or strategies), as well as initiative or working groups operating in this area;

- environmental standards, initiatives and management in the field of tourism services, which is an important factor for the development of eco-tourism entrepreneurship, eco-certification initiatives, waste sorting, alternative energy sources, biodiversity protection, environmentally friendly production by farmers. Nowadays, it is highly necessary to adopt high environmental standards.

- public-private partnership experience in the field of tourism; an important role in the transition to a green economy. In many leading foreign universities, such as Oxford, Harvard or the London School of Economics, the concept of a "green" university is implemented. Ecotechnologies are introduced there, environmental education is being developed, environmental campaigns are being conducted, and environmental topics are being integrated into the educational program.

\section{E. Measures of State Support of Scientific and Educational Projects Related to a Green Economy}

This is a large-scale direction that provides such global actions as modernizing scientific area; launching new scientific schools and implementing strategic R\&D programmes for green technologies; training competent scientific and technical personnel; attracting funds to projects of private investments (including venture funds and PPP for the development of research infrastructure).

According to international studies, universities can play an important role in the transition to a green economy. A number of leading foreign universities, such as Oxford, Harvard or the London School of Economics, implement the concept of a green university. Eco-technologies are being introduced, eco-education is being developed, environmental campaigns are being held, and environmental issues are being integrated into the curriculum.

For universities, it is possible to purposefully implement appropriate educational programmes, to develop professional competencies necessary for a green economy and environmental innovations or green technologies.

\section{INNOVATIVE MECHANISMS FOR THE DEVELOPMENT OF ENVIRONMENTAL ENTREPRENEURSHIP IN COASTAL AREAS}

Environmentally oriented economic entities act as a link in the activities aimed at restoring the environment. This can be wastewater and air treatment, production and consumption waste processing, eco-tourism, power generation from recycled materials, etc.

Natural resources and environment conservation is the main objective of environmental entrepreneurship in coastal areas, while environmental services and profits from environmentally friendly production come after that. Examples of environmental entrepreneurship in coastal areas can be the improvement of territories for various applications, with regard to their environmental characteristics, ecotourism and green construction.

It is certainly worth noting that environmental entrepreneurship as an economic activity must meet a number of criteria [8].

The first criterion is a charter consolidation of its main activity to implement works and services, produce goods intended for environmental protection. 
The first direction is the assessment of compliance with The second issue is participation in various federal and regional environmental and natural resource programmes as an executor of the state and municipal order.

The third thing is implementation of works and services, as well as manufacturing of products aimed at restoring the natural potential and meeting the needs of environmental protection activities.

Finally, the fourth criterion is proportion predominance of products, works and services for environmental purposes in the total volume of production [9].

To ensure sustainable development of coastal areas, it is necessary to adopt programmes supporting environmental entrepreneurship, which will help increase investment activity in such areas. Such measures may include:

- providing financial benefits to organizations whose activities are aimed at preserving and improving the environment quality in coastal areas;

- raising a venture capital or investment funds, both regional and private, to support environmental entrepreneurship;

- providing legal benefits to organizations whose activities are aimed at preserving and improving the environment quality in coastal areas;

- ensuring co-financing of environmental investment projects by means of various voluntary contributions of enterprises and organizations, as well as environmental fines and payments;

- establishing infrastructure providing services and resources necessary for environmental business entities;

- increasing management effectiveness of local and state governments to support small business, since effective management can give a necessary start to intensive ecological business development, and also attract additional investments to coastal territories [10].

Another area of environmental business development in coastal areas is establishing public-private partnerships, in particular tourism concession. Tourism concession means transferring to a concessionaire one or more state-owned historical, natural or social and cultural objects to use exclusively for tourism purposes in construction, operation, management and maintenance under certain conditions.

Today it may safely be said that one of the economic development directions in coastal territories is the market development of environmental goods and services (EGS). In coastal areas, EGS markets are widely developing in such directions as environmental support of enterprises, environmental expertise, engineering and environmental surveys and others. However, we believe that the most promising mainstream development areas of EGS market are the following: regulatory requirements for environmental protection of coastal areas, or environmental audit.

The second direction implies a certain type of liability insurance for organizations functioning in the coastal territories, which activities cause environmental damage to coastal territories, or environmental insurance.

Finally, the third direction of EGS market development in coastal areas is related to managing environmental and nature protection activities in coastal areas, or environmental management.

Stimulating and developing entrepreneurship in coastal areas require a number of measures:

- development of material and technical base aimed at servicing tourists, which involves creating visit centers, developing and arranging ecological paths and pedestrian routes;

- scientific support for entrepreneurship development to determine the current state of the ecosystem, as well as recreational load calculation and monitoring;

- tourism product promotion;

- involvement of enterprises and local communities in entrepreneurship development at the park's site.

It should be noted that main opportunities of the ecological market are the following:

- improving existing products by adapting them to new environmental requirements;

- designing fundamentally new products and even creating specialized companies for their manufacture;

- attracting foreign investment;

- providing environmental services as information, consulting, expert assistance in solving environmental problems, environmental specialist training, etc.

\section{CONCLUSION}

For further sustainable development of coastal areas, governments need to develop a strategic approach based on principles of the green economy.

Various tool groups can be used to promote a green economy in coastal areas:

- economic tools (green taxation, subsidies, environmental payments);

- administrative and order tools (orders and directives, prohibitions, limits on emissions or licensing procedures);

- voluntary tools (voluntary agreements between state structures and associations of private entrepreneurs (green contracts or unions), information, management systems). 
[8] Boboshko V. I., Gusev A. A., Potravny I. M. Features of environmentally oriented small business in Russia/ V. I. Boboshko, A A. Gusev, I. M. Potravny // Economics of environmental management, No. 5, 2006, pp. 31-40. (in Russian)

economy requires authorities to do much more than simply choose a policy tool or instrument from a list of green economic policies. This requires setting clear goals and objectives; analysing interactions and trade-offs among different policy options to achieve the objectives (to effectively design and implement priority actions); reviewing policies over a long period of time as part of an ongoing adaptive management process (to monitor progress).

For most countries, this is a sophisticated task requiring institutional and financial solutions (removal of barriers that make green markets unattractive; innovative development of financial tools, green infrastructure, adequate data and information (on pollutant emissions and discharges, cost indicators and estimates of biodiversity and ecosystem services, etc.) necessary for the successful development and implementation of green public policies).

According to integrated coastal management, planning should be carried out through developing action policies and setting the main objectives for the development of coastal areas. Action policies should be aimed at coordinating development strategies of industries or individual enterprises to reach an overall development in coastal areas. Thus, sustainable development of coastal territories should be focused on a company's economic activities in accordance with principles of sustainable development and subsequent integrated management.

\section{REFERENCES}

[1] Gassiy V.V., Belyaeva E.A. Potential of protected areas in the implementation of green growth strategy of regional economics // In the book: Problems. Hypotheses. Answers: The Science of the XXI century collective monograph. Scientific Publishing Center "Apriori". Krasnodar, 2016, pp. 56-78. (in Russian)

[2] Arumova E. S. Problems of development of green economy and their contribution to the socio-economic development of specially protected natural territories // Science today: the theory and practice of the materials of the international scientific-practical conference: "Dispute" Science Center, 2016, pp. 47-48. (in Russian)

[3] Panaseykina, V. S. Ecological and economic aspects of development of coastal territories in Krasnodarsky Krai / V. S. Panasejkina // Ekologicheskaya, promyshlennaya i energeticheskaya bezopasnost 2017 : sbornik statej po materialam nauchno-prakticheskoj konferencii s mezhdunarodnym uchastiem "Ekologicheskaya, promyshlennaya i energeticheskaya bezopasnost - 2017" (September 11-15, 2017). (in Russian)

[4] From shipyards to seas: green trends in shipbuilding [Electronic resource] / / Internet portal "Maritime-zone". URL: http://maritimezone.com/articles/green-features-in-shipbuilding/

[5] Khutorova N. A. Green growth as a new development trend in the Russian economy / A. N. Khutorova // Lesnoy Vestnik, No. 1, 2015, pp. 190-198. (in Russian)

[6] Egorova M. S. Practice of stimulation of transition to "green economy": international experience [Electronic resource] / M. S. Egorova // Modern scientific researches. Release 1. Concept. 2013, pp 1651-1655. - URL: http://e-koncept.ru/2013/53333.htm. (in Russian)

[7] Belyaeva E. A. Specially protected natural territories: transition to sustainable development / E. A. Belyaeva // Economic development of Russia: traps, forks and rethinking: Proc. Intern. Sc.-Prac. Conf. / ed. I. V. Shevchenkho, Krasnodar, 2017, pp. 75-78. (in Russian)

[9] Arumova E. S. Mechanisms of state support of transition of coastal territories to a green economy / E. S. Arumova // Modern problems of project management in investment and construction sphere and nature management. Materials of 8th International scientific and practical conference of the department of project management and programmes, 2018, pp. 325-328. (in Russian)

[10] Kropinova E. G., Afanasyeva E. P. Sustainable development of coastal areas as a basis for integrated coastal area management / E. G. Kropinova, E. P. Afanasyeva // Bulletin of the Immanuel Kant Baltic Federal University. Series: Natural and Medical Sciences, 1, pp. 140147. (in Russian) 